

\title{
Bankruptcy Laws Around Europe (1850-2015): Institutional Change and Institutional Features
}

\author{
Abstract \\ Despite the relevance of bankruptcy law for a number of key issues regarding business \\ functioning and organization, little is known about the features and evolution of these \\ legal institutions over time and space. This paper starts to fill this gap in current \\ knowledge by analyzing a new data set providing consistent information about key \\ features of bankruptcy law between 1850 and 2015 in the thirty largest European \\ economies. Regarding institutional change, our analysis supports the established view of \\ a link between macroeconomic changes and the introduction of procedures alternative to \\ bankruptcy. However, this process shows significant differences at the national level, \\ making it difficult to support the idea of change as the result of belonging to a given legal \\ system (French; common law; Scandinavia; Germanic), or the degree of economic \\ development. Instead, change in bankruptcy institutions seems to be a product of, and \\ contributor to, the wider process of individual state formation. Similarly, the features of \\ bankruptcy procedures seem to confirm this picture: Looking at their possible outcomes, \\ the right to begin proceedings, and degree of application to different types of debtors, \\ national differences appear deep and persistent, despite a generalized pattern of \\ convergence over time toward a less punitive approach to bankruptcy.
}




\section{Introduction}

"In the beginning there were markets"_-Oliver Williamson argued 1 —and the markets' function par excellence is to select among firms, promoting worthy concerns and eliminating the unviable ones. Timelessly, and without friction and costs, an efficient selection among businesses and entrepreneurs is made, and economies that let the markets operate unfettered are allowed to prosper. However, for those who get their hands dirty digging into the reality of the history of business, a very different story emerges. The market's function to select viable firms is, at least, mediated by, and, at most, fully replaced by a wide set of institutional settings. Among these institutions, the main player is bankruptcy (and insolvency) law. ${ }^{2}$ If we consider, as is widely recognized, that these institutions are a key mechanism of capitalist economies, it is perhaps not surprising to discover the influence they have had on fundamental aspects of business organization and functioning. Historically, the choices of forms of governance, ${ }^{3}$ attitudes toward risk-taking across class and gender, ${ }^{4}$ the development of credit markets, ${ }^{5}$ the size and structure of firms in various nations, ${ }^{6}$ all have been shaped by legal institutions, in particular the ones dealing with failure and restarting.

Although the influence of these institutional settings on business organization has been (and still is) the subject of wide investigation in economic and business history, relatively little attention has been paid to the much broader context: the historical reconstruction of the features of bankruptcy laws over time and space. So, currently, we are unable to readily compare the fate the same firm would have faced in Britain had it 
been declared bankrupted in 1850 as opposed to 1950 . Similarly, we do not know what would have happened to a firm in, say, Sweden in the 1970s, compared to Belgium or Germany in the same decade.

Just as importantly, little is known about the patterns of change of these laws over time. The lack of research on this topic is perhaps not surprising given the number of considerable methodological issues involved: the definition of the time span, the number of countries to be covered, the variables to be included, the fact that sources are dispersed, fragmented, and written in a number of different languages. Furthermore, the assumption that institutions naturally converge toward the most effective ones, has perhaps led many to believe that a reconstruction of bankruptcy and insolvency laws is essentially redundant. A few facts should suffice to dispel these doubts. Around the turn of the nineteenth century, treating a case of bankruptcy took, on average, about a year in England and Germany, a few more months in France, and about three times as long in Italy. In England, about 40 percent of firms would have used a prebankruptcy arrangement, about one third in France, and less than 5 percent in Italy, while in Germany such deals were simply not available as part of bankruptcy procedures. ${ }^{7}$ Yet, in 2016, more than a century later, and after the 2007-08 financial crisis had severely tested the functioning of insolvency regulations, it appeared that little had changed, with the European Commission noting that across the EU bloc, "despite reforms in the area of insolvency, rules still diverge and remain inefficient" ${ }^{\prime 8}$ in a number of countries.

The absence of such research also reflects a significant gap in our understanding more generally of long-term institutional development in a comparative context, with 
only a handful of studies on this topic despite the longstanding acknowledgement of their value to a range of disciplines. So, whereas bankruptcy and insolvency laws are key "rules of the game," the issue of these institutions and patterns of change, so central to business history, has yet to be tackled, and the fundamental questions about the nature of bankruptcy laws in a comparative perspective and of their evolution over time are therefore still to be answered.

The purpose of this paper is to start the challenging task of addressing this gap in the business history literature in two ways. First, the core contribution of the paper is the collation, in a consistent and systematic way, of detailed information on the most important features of bankruptcy and insolvency laws in the largest thirty European economies in a long-term perspective. The paper spans the period 1850-2015 and is based on qualitative information, derived from legal documents and secondary sources, turned into a data set of quantitative measures. Whereas a similar methodology has been used for an analysis limited to the core European countries for the period 1808-1914, ${ }^{9}$ this paper expands the study to a much broader set of countries and links the trajectory of legislative change from the mid-nineteenth century to the current day. The aim is to provide researchers with a set of coherent data that can be used either in national or in comparative studies, both in terms of bankruptcy and insolvency law, but also in terms of long-term institutional change more generally. Second, information from the data set is also analyzed in an attempt to identify some general trends in the evolution of bankruptcy legislation and legal procedures over time, and present some hypothesis for possible causes behind such trends. Clearly within the limits of a paper such as this, it is not 
possible to explore each of these trends in detail, however, the objective is to help move the debate regarding institutional change beyond the constraints of any particular theories, and open up new avenues for research.

This article is organized as follows: Section 1 describes the sources and methodology behind the longitudinal data collection. Sections 2 and 3 use the information from the data set to analyze the introduction of various types of solutions across time and space and of their various features: who could apply to them; outcomes possible; conditions demanded; who made the final decision on their acceptance. Section 4 analyzes a specific indicator - the total number of outcomes available in various systems - which we consider as a basic proxy of the "quality" of bankruptcy and insolvency institutions. Section 5 offers some concluding remarks.

\section{Methodology and Definitions}

A study of this kind raises a number of significant methodological challenges. The first issue is the geographic focus. We adopted a strategy of covering the thirty largest European economies by GDP in 2015, a list of which is presented in the appendix (table A). The sample thus includes the majority of the twenty-eight countries being part of the EU in the same year (with the exclusion of Cyprus, Estonia, Latvia, and Malta), plus other important European economies such as Norway, Russia (and Belarus), and Switzerland. Some of the countries included did not exist as independent (or legally autonomous) states for the entire period, hence the number of countries in the sample changes over time. Specifically, in the period up to World War I, the existence of the Austro-Hungarian and Russian empires, and the lack of independence for some of the 
benchmarks, of Romania or Bulgaria, reduced the number of independent (or legally autonomous) countries to twenty in 1850-70, twenty-one in 1890, and twenty-two in 1915. ${ }^{10}$ The number increases to twenty-five during the interwar period, with the temporary independence of Lithuania and the foundation of Czechoslovakia, and of the State of Slovenes, Croats, and Serbs (lately Yugoslavia), and remains almost the same until the fall of the Berlin Wall (twenty-four, as Lithuania losses its independence after World War II). The political fragmentation that followed results in the sample size of thirty.

However, the number of observations actually included in each benchmark does not necessarily coincide with the number of independent or legally autonomous countries. For the period up to 1910, all countries are represented in the analysis; as for political entities that were parts of empires (or other states), we simply used data referring to them. ${ }^{11}$ Between the benchmark 1928 and 1975, the spread of communism in eastern Europe ensured these institutions disappear in some of these countries, hence the number of observations varies accordingly: twenty-six in 1928 and 1938, nineteen in 1950, and twenty-two in 1975. ${ }^{12}$ All thirty countries (with the exception of Belarus in 1995) are represented in the last two benchmarks, 1995 and 2015. Overall, nineteen countries are represented over the whole period 1850-2015.

In terms of time span, the analysis aims to capture changes and the evolution of bankruptcy law over the last century and a half by providing a series of snapshots taken at ten benchmark years. We take 1850 as a starting point because the relevant literature indicates that cultural changes toward debts, and economic transformations due to the 
Industrial Revolution, led, a couple of decades later, to a Pan-European wave of changes in bankruptcy and insolvency law. ${ }^{13}$ New legislations, in general, broke with traditional punitive ways of dealing with the issue, embracing a more tolerant and supportive philosophy. ${ }^{14}$ The snapshot taken in 1850 , therefore, crystallizes the reality of legal institutions before the subsequent transformations, and allows for a comparative analysis of the changes. The remaining nine benchmarks have been selected to allow us to observe the impact of great political events in European history—such as the two world wars and the fall of communism — but also of the main economic transformations represented by the first and then second industrial revolutions (three benchmarks between 1870 and 1914); the economic instability and crises of the interwar years (two benchmarks between 1918 and 1939); the "Golden Age" of European economic growth (two benchmarks between 1950 and 1970); and the end of communism and the advent of the recent wave of globalization (benchmarks 1995 and 2015).

In regards to the type of data collected and studied, the very wide scope of our analysis forced us to focus exclusively on "formal" aspects of bankruptcy, that is, the features of the official procedures contained in legislation. We are fully aware that such an approach comes with limitations: Historically, in some countries formal institutions were rarely used while, allegedly, extrajudicial solutions were very popular. Although a systematic study of this topic is beyond the scope of this paper, where possible the paper refers to available information on the nature of enforcement mechanisms and actual functioning of procedures, in order to give the reader at least a sense of the degree of usage of formal solutions to bankruptcy. 
In order to study formal aspects of legislations, we start by defining three ideal types of solutions (bankruptcy procedure; prebankruptcy procedure; businesses relaunching procedure) and then analyze when these appeared in the countries under analysis, and which specific characteristics they took.

Bankruptcy procedure in the narrow sense is the traditional and basic channel to deal with insolvent or illiquid firms and businesses. It requires a formal declaration of bankruptcy and is a full judicial remedy, in the sense that it takes place in a court. Even this basic solution, however, can vary in its practical implementation. Among key aspects, historical literature has looked at the issue of the possible outcomes of the procedure, its coverage in terms of legal entities allowed to use it, and who had the right to open it. Traditionally, bankruptcy was based on the liquidation of the debtor's business and the sale of its assets but, over time, legal systems started allowing also the possibility of closing the procedure via a settlement with the creditors comprising the repayment of a given percentage of the debts. This was a very important change, with nineteenth- and early twentieth-century commentators stressing the key role of this solution in increasing the overall efficiency of bankruptcy procedures, in particular in terms of reducing waiting time and increasing payments to creditors. ${ }^{15}$ Therefore, in the paper, we record for each benchmark whether or not bankruptcy allowed for a composition as well as liquidation. Another key aspect of bankruptcy relates to its application. Over the course of the nineteenth century, and up to the 1930s, fierce debates arose among legal scholars, both in common and civil law countries, on whether this solution should have been reserved for merchants (or traders), as common in French-derived legislation, or open to all 
categories, as was the case in England after 1861 or Germany since $1877 .{ }^{16}$ Considering that nontraders, in general, were exposed to a much stricter legislation, opening up bankruptcy to them was part of a generalized attempt at mitigating conditions for debtors that characterized much of the later nineteenth-century reforms. This approach was the result of the growing awareness of two facts. The first one, that economic failure was not necessarily the result of misfortune. Second, that encouraging honest yet unlucky debtors to use the bankruptcy system would have generated advantages to creditors by limiting the use of extrajudicial solutions or the dissipations of resources via procrastination over the declaration of bankruptcy. ${ }^{17}$ Connected to this point, a third fundamental aspect of bankruptcy procedure concerns its opening. Traditionally, it was up to creditors to declare the bankruptcy of debtors but, over time, debtors were allowed to make the first move themselves or, in other cases, courts could act independently. In the paper, we thus collect information on this aspect, recording whether bankruptcy law applied to all creditors or just to some specific groups, as well as information about the right to start the procedure.

The introduction of prebankruptcy proceedings or arrangements, ${ }^{18}$ the second ideal type of procedure we use in the paper, is considered one of the major institutional changes occurring in the history of bankruptcy. ${ }^{19}$ These solutions represented an alternative and parallel path (although in various cases failing to obtain it pushed debtors back to the bankruptcy track) requiring an agreement with (a variable majority of) creditors to be reached before the actual declaration of bankruptcy. The agreement was supervised by the court and, often, also subject to its approval. Some early examples of these procedures were the concordat préventif in Belgium (1883), the deeds of 
arrangements in England (1887), and the liquidation judiciaire in France (1889). As compared to bankruptcy procedures, these solutions had in common the aspect that they do not lead to the formal declaration of bankruptcy for debtors. This avoided the need for debtors to be "rehabilitated" in order to run businesses and, in countries such as France and England, the loss of civil and economic rights that came with the legal condition of a bankrupt. ${ }^{20}$ As with bankruptcy, these proceedings differed in various ways among countries. Although geared toward reaching a settlement over payment of a given share of debts, in some legal systems they could also allow for the liquidation of the creditor's business. This key difference is recorded and analyzed in the paper. A second difference concerned ex ante conditions (usually guarantees to be able to pay at least a given share of unsecured debts) that had to be respected in order for a prebankruptcy procedure to be allowed. Historical research has showed that such conditions could dramatically reduce the usage of these procedures, as was the case in Italy or England before compositions before bankruptcy were replaced by deeds of arrangements. ${ }^{21}$

The third ideal type of procedure we analyze in the paper are solutions to bankruptcy specifically aimed at keeping businesses alive and relaunching them, what in the paper we call relaunching procedures. A milestone in the history of the evolution of bankruptcy is the understanding that a firm has a higher value as an ongoing concern compared to the sum of the market price of its individual assets, and that saving a firm avoids the economic and social costs that come with business liquidation via specific procedures. $^{22}$ In looking at this type of solution, a key distinction must be made between proper prelaunching procedures and the prebankruptcy procedures described above. 
Although in contemporary debates the latter are often seen as company-restructuring devices because of the option of keeping firms alive by reaching a settlement, it is very clear that historically this was not the case, and business relaunch was not their aim. As stressed by contemporaries and by historical literature, these procedures were, instead, part of the trend described above, aiming at reaching better deals for creditors by offering debtors less punitive solutions. ${ }^{23}$ Instead, examples of the business-saving approach characterized different solutions, such as the English administration or receivership, the Belgian administration controlee, and the Italian amministrazione controllata. These procedures vary in nature, but they all rely on some or all of the following elements: a period of "freeze," when creditors are not allowed to push the business into bankruptcy (debt moratorium); the conversion of credits into securities of a new company, which replaces the one in distress; the provision of an industrial plan for the future; and the replacement of existing management. In this paper, we record when these institutions started appearing and what form they took. In particular, we distinguish between the introduction of the mere debt moratorium (often unable to address the problem of business relaunch, and in very limited use) and the appearance of more complex solutions.

Finally, as a synthetic measure, we analyze the number of possible outcomes offered in each country at each benchmark as a way of assessing the menu of options available to deal with bankruptcy at that time. To calculate this variable, we add the total number of procedures (prebankruptcy, bankruptcy, and relaunching), also taking into account their possible outcomes. So, for instance, a country where there is a 
prebankruptcy procedure that can only lead to composition and where bankruptcy procedure can lead to liquidation or composition, and there are also two different relaunching procedures, will have a total of five outcomes (one for prebankruptcy, plus two for bankruptcy, and plus two for relaunching). ${ }^{24}$

The approach we take in this paper is based on the following steps. Using a wide set of secondary sources (sources are described in the appendix), first we populate table A (in the appendix), which records which law applied at each country/benchmark, the changes (or lack of) vis-à-vis the previous country/benchmark, and the sources we used in each case. Because of the nonhistorical nature of some sources, for each benchmark/nation we cross-referenced at least two sources (when possible). Changes in the legislation are considered only in the following cases:

- Provision of new legislation replacing the previous one. We use this definition even when, as in many communist countries, the previous legislation has not been active for a period of time.

- Introduction of a prebankruptcy or relaunching procedure, when distinct from the introduction of a bankruptcy law.

- Changes in one key aspects of the procedures described above (possible outcomes; opening of the procedure; inclusion of different types of debtors; ex ante conditions)

This specific definition of "change" results in the omission of some cases of known reforms that have been identified in the literature, ${ }^{25}$ and does not fully capture the dynamics of change in common law countries, where judges attitudes could deeply 
influence the meaning and actual functioning of procedures. ${ }^{26}$ Despite these limitations, we believe that the criteria we have adopted for "change" enables the identification of the main episodes of institutional change in a consistent way.

The second step of our analysis (in section 2) consists of charting such change across time and countries in order to try to identify possible similarities and to look at the relationship between economic, political, and legal transformations.

In the third step of the analysis, for each country/benchmark, we use a wider set of sources, which also includes primary sources such as laws and acts (either in the original language or translated,) to analyze the details of the legislation in order to populate the spreadsheet. ${ }^{27}$ This information is then analyzed in sections 3,4 , and 5 .

\section{Institutional Change: The Nature of Legislative Process}

In this section we analyze the evolution of bankruptcy law across European countries in terms of year of introduction and number and types of changes. The aim is to capture features such as the existence of national trends, as well as the persistence of institutions when facing exogenous shocks.

\section{When Countries Passed a National Legislation "First"}

At the beginning of the nineteenth century, bankruptcy norms included in the French commercial code of 1808 were the basic model for most European countries and were directly used in Belgium, Switzerland, and some of the German states. By the 1850s, however, a process of establishment of national laws was well underway, although when this process was initiated differs between countries. We can posit various potential reasons for this: the degree of political and institutional stability of each nation, the state 
of its economic development, and, as suggested by dominant economic literature, the belonging to a specific "legal family" (French; Anglo-Saxon (common law); Scandinavian; German). ${ }^{28}$ Table A shows that at the first benchmark (1850), more than 70 percent of the countries included in the sample ${ }^{29}$ had a national specific system of bankruptcy procedures - although not necessarily a freestanding bankruptcy law, as sometimes norms were part of the commercial code or provided via "ordinances." By the following benchmark (1870)—and with the inclusion of Belgium, Germany, Norway, Finland, and Ireland — nearly all the countries in the sample (around 90 percent) had implemented a national bankruptcy system. Two countries (Romania and Switzerland) completed the process by the following benchmark, with Bulgaria passing a national law by the 1910 benchmark.

In seeking possible explanations for these results, the issue of "legal family" does not appear to be significant, as the pattern of institutional change shows little evidence of clustering according to specific legal groups. ${ }^{30}$ Similarly, the degree of economic development appears a poor explanation, if we consider that relatively backward countries such as Russia, Poland, and Spain had national legislation before emerging industrial powers such as Germany or Belgium. What appears to be the case is that the establishment of a national commercial code and a bankruptcy law was an important component in the process of state building, as the advent of political stability (or the age of consolidation of state power) seems concurrent with the appearance of national legal institutions in this field. The process displayed a complex relationship with the existing models. For instance, whereas Italy and Greece de facto almost simply translated the 
French code in an attempt at demonstrating their consolidation as advanced economies, Belgium and Holland tried to mark their independence by making nation-specific changes to the law they had inherited from their previous rulers. ${ }^{31}$

\section{Changes by Country}

Other than the date of introduction of the initial bankruptcy law, another interesting aspect is the number of changes over time as defined in the previous section. Figure 1 below plots, for each country, the number of changes from the 1870 benchmark onward. Likewise, the timing of the introduction of bankruptcy procedures gives some indication as to the validity of the idea that belonging to a specific legal family might dictate some similarities in the process of institutional (legal) change.

Figure 1 Number of total changes to bankruptcy law by country: 1870-2015

Note: Change defined as: 1) provision of new legislation replacing the previous one; 2) introduction of a prebankruptcy or relaunching procedure, when distinct from the introduction of a bankruptcy law; 3) changes in one of these aspects: possible outcomes of procedures; opening of the procedure; inclusion of different types of debtors; ex ante conditions.

Data sources: See text.

The evidence from Ireland and England, displaying six and five changes respectively against a modal range of three changes, at first glance suggests that their "legal family" might have played a role, but this stands at odds with other cases. For instance, clear differences exist between Norway and Sweden (respectively three and five changes), despite their cultural ties and belonging to the same legal family. At the same 
time, collective political stability seems to be a good explanation for similarities - for instance in the three Benelux countries, the basic legal frameworks were based on late nineteenth-century laws (with some changes in the 1930s) for most of the period, and in general, these countries show a limited number of changes. On the other hand, countries formerly belonging to Yugoslavia (Croatia, Serbia, and Slovenia) and to a lesser extent Czech Republic display relatively high numbers of changes, but this appears to be in line with a common history of multiple political changes, rather than the collective belonging to a legal family.

Changes by Benchmark and the Introduction of "Alternative” Procedures

Instances of legal change not only differ across countries but also chronologically, with phases of rapid changes between periods of calm. Figure 2 plots the number of changes occurring at each benchmark as percentage of the number of existing independent (or legally autonomous) countries.

Figure 2 Number of changes to bankruptcy per benchmark years as percentage of the number of countries included in the sample

Data source: See text.

Figure 2 shows a period of a high and growing number of changes up to World War I, followed by another (lower) peak at the end of the 1930s. After a long period of calm after World War II, the process of legal reforms gathered fresh momentum from the 1990s onward, with the number of changes being the absolute highest in 2015.

The period up to 1910 was a phase of deep economic change with profound technological transformation that characterized the Second Industrial Revolution. As 
argued in section 1, these economic changes progressively revealed the inadequacy of traditional punitive bankruptcy law, and triggered institutional transformation. This took place mainly via the introduction of alternative prebankruptcy procedures. Figure 3 shows the share of countries that, at a given point in time, had such procedures. The figure gives data both for the total sample at that point in time, and for the countries that are constantly present in the sample from 1850 onward.

Figure 3 Share of countries having prebankruptcy procedures

Note: Prebankruptcy procedures defined as solutions leading to either liquidation or requiring an agreement with (a variable majority of) creditors to be reached before the actual declaration of bankruptcy.

Data source: See text.

While in 1850 only a limited percentage (about twenty per cent) of countries had such procedures, by 1910 this had risen to about 60 percent, something that helps explain the high number of changes occurring to bankruptcy laws during this time. It must be noted, however, that the process of introducing these procedures continued after World War II, with the share of countries having at least one type of prebankruptcy solution jumping to more than 80 percent in 1950 for the total sample. These results offer some qualification to the established view linking the introduction of prebankruptcy procedures to an awareness of the inadequacy of traditional remedies in a rapidly changing economic environment. The institutional response to similar economic and cultural changes took place along national lines, and according to internal national considerations. Among them, we can include the approach to the German codes, which emerged as a leading 
alternative to the French model ${ }^{32}$ and did not include prebankruptcy procedures. In conclusion, the process of institutional convergence suggested by the literature is still visible, ${ }^{33}$ but it appears much slower and more complex when the sample of countries is expanded.

In order to explain the timing in the changes occurring to bankruptcy law, we have to consider another institutional change occurring in the period up to World War I: the introduction of what we defined as relaunching procedures. Figure 4 plots the percentage of nations that, at a given point in time, had such procedures. The figure gives data both for the total sample at that point in time, and for the countries that are constantly present in the sample from 1850 onward.

Figure 4 Share of countries having a relaunching procedure (including Moratorium) Note: Relaunching procedures defined as solutions to bankruptcy specifically aimed at keeping business alive and relaunching them.

Data source: See text.

Our data, independently of which sample we consider, shows a clear increase, with the biggest jump occurring in 1910. This picture stands at odds with the idea that major economic shocks—-specifically the 1930s Great Depression — triggered such legal change. Evidence of a possible link between the 1930s crisis and the need to introduce legal devices to support businesses in trouble could be found, at first glance, in the tone (and even the title) of coeval literature both in Europe and the United States. ${ }^{34}$ as well as in the almost parallel introduction of this type of procedure in various countries, for instance Belgium (1934) and Italy (1942). Our data, however, does not support the 
existence of such a clear-cut connection. This result is, in part, due to having included among this type of procedure typically nineteenth-century remedies such as debt moratorium. Such devices had little practical use or effectiveness, as clearly shown in the cases of nineteenth-century Netherlands or Italy, where businesses could apply to such a procedure only when the assets exceeded the liabilities. ${ }^{35}$ Yet, however ineffective, the early introduction of these devices can be seen as evidence of the fact that policy makers seem to have been concerned with the issue of avoiding undue liquidations of firms earlier than we previously believed. Furthermore, the lack of concurrence between the introduction of relaunching procedures and the Great Depression can also be explained by considering that the 1930s economic shocks probably stimulated adaptations to existing institutions rather than triggering the introduction of entirely new ones. ${ }^{36}$ This conclusion is supported by nation-level evidence: In Belgium, for example, the Administration Contrôlé was introduced in 1934 but only for two years; in Italy special case was made for banks and insurances, but there was no reshaping of bankruptcy law overall; whereas in England, as stressed by contemporary commentators, "the ... economic crises produced no basic change." ${ }^{37}$

The benchmark years in the Golden Age (1950 and 1975) are notable for their lack of changes, and this is confirmed by our data. This is unsurprising given the existence of communist states and the long-term stable economic growth during the period.

The increase in the number of changes from benchmark years 1975 and 1995 is clearly caused by the collapse of communism and its aftermath, with the emergence of 
new capitalist European nations, which required the institutions to deal with business failure.

The 2007-8 financial crisis is one of the main causes of the high number of changes for the 2015 benchmark. However, many of the changes relate to postcommunist nations. The data supports the argument that their initial postcommunist bankruptcy laws in the 1990s were hastily formulated institutions that struggled to cope with the economic volatility of the period, and consequently underperformed. Specifically, data on the number of outcomes available by law (arguably the most relevant synthetic statistic about the "quality" of bankruptcy institutions) shows a sharp rise between 1995 and 2015 for postcommunist countries (see sections below for details). ${ }^{38}$

\section{Institutional features: procedures across time and space}

The introduction of legal institutions across time and space, analyzed in the previous section, does not seem to indicate that European countries smoothly converged toward similar architectures, but rather it highlights the extent to which national trends shaped different paths of development. To analyze these issues, we consider some of the features of various institutional devices (bankruptcy and prebankruptcy procedures).

\section{Bankruptcy}

The first aspect we investigate is the share of countries whose bankruptcy procedure could lead to either a liquidation of the debtor's business or an agreement (settlement) with creditors - a solution often believed to be a "softer" alternative for debtors. Figure 5 shows, specifically, the share of countries whose bankruptcy procedure could end up with liquidation of the debtor's assets or a composition with creditors. 
Figure 5 Share of countries whose bankruptcy procedure could lead to either liquidation or settlement

Data source: See text.

The data shows that already by the 1850 benchmark, and contrary to the image of traditional bankruptcy law as oriented toward liquidation, the vast majority of countries (between 80 and 95 percent depending on the sample considered) also allowed for a settlement. Up to 1975 , this share remains fairly constant among the nineteen countries always represented in the sample, while for the total sample it seems to decline and increase again, while never going below 60 percent. In the last two benchmarks this share declines as some western countries always contained in the sample adopted liquidationonly bankruptcy procedures (Switzerland-2015 and Portugal-1995), as did a number of eastern European states postcommunism—Croatia, Czech Republic, Hungary, and Romania. Hence, the decline appears more marked when the total sample is considered. It should be pointed out that the persistency, and occasional introduction of liquidation-only bankruptcy procedures in the last two benchmarks, can be explained by the parallel introduction of ad hoc measures to relaunch companies outside the main bankruptcy pathway, for example via the use of prebankruptcy procedures or equivalent institutional devices. As such, the recent trend seems to indicate the introduction of more polarized and specific solutions, leaving bankruptcy the role of pure liquidation for extreme cases.

As far as the application of bankruptcy law was concerned, figure 6 shows the share of countries whose bankruptcy law was open to all debtors, and therefore did not distinguish between traders and nontraders. 
Figure 6 Share of countries whose bankruptcy procedure applied to all types of debtors Data source: See text.

Irrespective of the sample considered, the data shows a very clear upward trend to 1938 (with the share passing from $30-40$ percent to $70-80$ percent), followed by a slight decline to around 60 percent in 2015. The trend confirms the established view of a progressive opening of procedures to a wider set of debtors (typically to nontraders), which led to lawmakers adopting a less punitive attitude, and the acceptance of the fact that bankruptcy was not necessarily an act of fraud. The data also illustrates the relative slowness of this process: By World War I, about 40 percent of the countries in the sample still discriminated among debtors. The most recent benchmark, 2015, suggests a change of direction with access to bankruptcy procedures becoming more selective. This change, rather than a reversal in the attitude toward debtors, can be explained by the parallel introduction of dedicated solutions for specific categories, confirming the pattern of an increasing number of more specialized solutions noted above.

Another dimension of bankruptcy concerns who has the legal right to initiate the procedure. Figure 7 plots the share of countries, for each benchmark, in which a given set of actors (only debtors; only creditors; only courts; debtors and creditors; debtors and courts; debtors, creditors, and courts) could initiate a bankruptcy procedure. Figure 7 Entities allowed to start bankruptcy procedures in various countries (as percentages of the number of countries considered).

Data source: See text. 
Overall, countries moved along a consistent trajectory of evolving from a situation with the power largely in the hands of creditors to a more balanced situation in which debtors and creditors (and court) could make the decision. So while the share of countries where only creditors could activate bankruptcy procedures declines over time (eventually disappearing in 2015), legal systems in which the decision could have been made by either debtors or creditors increases over time (with some fluctuations between 1938 and 1975) to become the most common situation in 2015. This evolution mirrors the pattern of the share of countries in which all subjects (debtors, creditors, court) were allowed to open procedures - this also increases over time, albeit with a slight decline in favor of the debtors/creditors from the 1950s. Court or debtors-only solutions appear in only a small number of instances, and a combination of the two is virtually nonexistent. This pattern suggests two things: first, the increasing attempts at making debtors collaborate with the functioning of official procedures that, at the same time, progressively lose their purely punitive nature; second, the consistent (possibly growing) role given to courts as a potentially "neutral" referee in terms of their ability to start procedures independently once the option is given to creditors and debtors also.

\section{Prebankruptcy Procedures}

A second area we can explore relates to the features of what we defined as prebankruptcy procedures. In particular, we are able to analyze two key aspects: the possible outcomes of these procedures and the existence of official preconditions for their acceptance by the courts or creditors. Figure 8 shows the relative share of countries for which prebankruptcy could lead to liquidation, composition, or both. ${ }^{39}$ 
Figure 8 Possible outcomes of prebankruptcy procedures (as percentage of countries having a prebankruptcy procedure)

Data source: See text.

The figure shows a revealing pattern. At the beginning of the period (1850), in the very few countries where prebankruptcy procedures existed, their outcome was equally divided between composition or composition and liquidation. In the following two decades, however, these types of procedures became common in most countries, but often directed toward liquidation (60 percent of cases in 1870), confirming their structurally different role vis-à-vis relaunching procedures. As argued by contemporaries, at their introduction, prebankruptcy procedures were not intended as devices to promote the relaunch of businesses, rather as a quicker, and probably less expensive-given the limited involvement of courts in the process-ways to collect debts. ${ }^{40}$ This role changes around the 1910s, when in about two-thirds of countries these procedures turned into prosettlement ones, and accelerated since the 1950 when liquidations in prebankruptcy procedures disappear. However, in about one-third of the cases these procedures keep the double outcome of liquidation or settlement, suggesting that their transformation into relaunching mechanisms is still noncomplete. Regarding this point, it is interesting to note how this feature varies even within a group of countries sharing the same legal background. For instance, common law countries (Ireland and England) have two solutions for a long time, but Ireland adopts the settlement-only pattern after 1995. Conversely, France and Spain both have the dual track system, but not Belgium — one of the most important French-law countries. Within Scandinavia, Sweden has two solutions 
but Denmark only one, whereas Germany is a famous case of a total absence of such procedures for a long period (prebankruptcy procedures were only introduced in 1938).

The final variable we analyze is whether or not prebankruptcy procedures were subject to the fulfilling of some ex ante conditions in terms of guaranteeing the payment of a share of unsecured debts. This is a fundamental issue, as ex ante conditions could have been a major deterrent to the use of these procedures and determined their degree of adoption across various countries. ${ }^{41}$ Figure 9 plots the share of countries having prebankruptcy procedures subject to ex ante conditions.

Figure 9 Share of countries in which prebankruptcy procedures were subject to ex ante conditions (in percentage of the number of countries having a prebankruptcy procedure) Data Source: See text.

At the beginning of the period, all countries which had adopted such procedures imposed no conditions, but a rapid change is visible between 1910 and 1928. Although still in a minority of countries ( 20 percent to 40 percent depending on the sample), the practice of having ex ante conditions became more common. This share stabilizes in the countries always present in the sample (apart from an increase to about 30 percent in 1995), while fluctuating to a great degree in the total sample. By 2015, both cohorts end up at a similar level. A possible interpretation of this pattern stems from considering the changing nature of these procedures over time. As long as they are simply used as a more efficient and cheaper alternative to straight bankruptcy no strings are attached to them. However, when such procedures start to show a clearer settlement-oriented pattern, then legislators feel the need to add stronger protection for creditors, as well as norms 
signaling the relative higher quality of creditors allowed to use softer solutions. When looking at specific national case studies, it seems hard to establish a general rule: Conditions are imposed for a long time in England, Italy, and Portugal, but for instance, not in France.

\section{Number of outcomes}

In this section, we analyze the pattern of the total number of possible solutions to the problem of insolvency as defined in section 1 . The general assumption we adopt is that the greater the number of outcomes available, the greater the ability of bankruptcy institutions to deal with complex situations in which a one-size-fits-all approach is not efficient. As such, we use the number of outcomes as a generic proxy for the sophistication and "quality" of bankruptcy institutions and we explore the possibility that such "quality" evolved, over time and space, parallel to the increasing growth and complexity of the economies.

To analyze, in general, the evolution of the variable over time, in table 1 we provide the descriptive statistics of our sample. ${ }^{42}$

\section{Table 1 here}

Table 1 shows a clear trend toward increase over time: The average number of total outcomes increased from 2.2 in 1850 to 4.3 in 2015 , when also the overall maximum (7) is the highest ever. The slight decline in 1950 and 1975 can be explained by the growing presence of communist countries for which this variable takes the value of zero. This pattern suggests that, in general, more solutions to bankruptcy and insolvency have 
been put in place as the complexity of the economies increases although the direction of causality remains to be established.

In table 2, we analyze the relation between economic and institutional development by providing, for five selected benchmark years, the average number of outcomes by countries grouped by quartiles according to levels of GDP per capita in each year. In order to obtain consistent national estimates of GDP, we have only included in the table countries that were independent at each benchmark.

\section{Table 2 here}

Results in table 2 confirm our hypothesis: Over time, countries grouped in the highest quartiles (Q1) of the distribution of GDP per capita also appear to have, in general, a wider menu of solutions to deal with insolvency and bankruptcy. In fact, the standard deviation of the variable appears to be lower for richer countries, suggesting also a higher degree of consistency of the quality of legal institutions among richer economies. Again, although the direction of causality remains to be established, it appears that more complex economies also possess more efficient legal settings.

To better understand the nature of the evolution in the number of outcomes across time and space, it is worthwhile analyzing whether differences existed across countries and country groupings. Table 3 below shows the number of outcomes at various benchmarks for groups of countries.

\section{Table 3 here}

In terms of the five largest economies of western Europe (by nominal GDP), England tends to show the highest number of outcomes, whereas Spain generally exhibits 
the lowest. Germany has a relatively low number of outcomes available over most of the period this research covers, largely because prebankruptcy solutions became available much later than in other advanced countries. Again, there seems quite a degree of variation between these countries in terms of number of outcomes and when changes occur.

The ex-communist states show some of the most pronounced increases between benchmarks. Their mean number of outcomes tends to be below the overall mean for the thirty-country sample — this is particularly true for the benchmark year 1995 but less so for 2015. The increase in the number of outcomes for 2015 compared to 1995 again suggests that relatively poor quality institutions were constructed in the immediate postcommunist period, probably to try and quickly gain legitimacy among Western countries, followed by progressive improvement.

Grouping countries according to different criteria such as common socioeconomic characteristics, physical proximity, or cultural profiles also generates some interesting results. For example, the Benelux countries display very similar trends in the growth of the number of outcomes (which is consistent with trends for other variables), and these values remain relatively stable across the period. Similarly, the group of Russia, Ukraine, Lithuania, and Belarus exhibit fairly similar patterns of outcomes across the period although, in contrast to the Benelux countries, the number of outcomes is persistently low-far below the mean in most instances. However, as with other aspects considered in this paper, in other country groupings where one might expect to see similarities in the number of outcomes, this is not the case. For instance, the Scandinavian countries are 
very similar for 1870 and 1890, but from 1910 onward the number of outcomes for each county differs quite noticeably. Similarly, apart from the period 1910 to 1950 , the data for England and Ireland is perhaps less closely related than expected, particularly as Ireland only gained independence from the UK in 1922.

\section{Conclusions}

Despite its relevance for the historical analysis of business organization and performance, little is known about the evolution across time and space of bankruptcy and insolvency laws. This paper offers a fresh contribution to this topic by providing a new and detailed picture of such evolution in Europe between the 1850s and 2015.

The aim is to help scholars undertaking analysis of business organization, entrepreneurship, or creditors protection within individual nations (looking at Italy, Britain, Germany, or comparing a handful of countries) by offering them data that enables such case studies to be placed in a wider comparative context.

The paper also provides some insight into the nature of institutional change in an area of key interest for business historians. In this regard, we can conclude that the data suggests the existence of a Pan-European phenomenon of institutional convergence, almost completed before World War I, centered around the introduction of procedure alternatives to bankruptcy, their opening to nontraders, and the progressive involvement

of debtors in the functioning of procedures. This early trend of homogenizing the level of protection of creditors and investors seems to be a relatively strong explanation for the features of long-term institutional change. 
"Path-dependency" in institutional change is certainly visible in some examples, such as the Netherlands, where the law only sporadically changed, but almost unnoticeable in other cases. The same can be said for external shocks. As expected, periods of economic stability, such as the post-World War II Golden Age, saw very little institutional change, while the industrialization of economies up to 1913 was paralleled by rapid and deep transformations in the law. On the other hand, the 1930s Great Depression left a lighter mark than usually assumed, and external economic events had very different impacts across nations. The missing link between the role of shocks and path-dependency of institutional change is likely to be in the realm of politics. In this paper we do not study this variable directly at a national level, but the evidence from the timing of the introduction of bankruptcy laws, as well as the effect of the fall of communism, clearly show that the process of state formation (hence, consolidation of the national institutional setting as a whole) had a clear and visible contribution.

Therefore, the central message of this paper is that in order to fully understand the evolution of institutional architectures, in this case the bankruptcy and insolvency laws, an approach is required that pays proper attention to the specific characteristics of these systems over time and avoids the trap of simplistic generalizations. 


\section{Bibliography of Works Cited}

Books

Bolaffio, Leone. A proposito della riforma del fallimento: puo', e come, estendersi ai debitori non commercianti? Turin, It.: UTET, 1923.

Bolaffio, Leone. Il concordato preventivo secondo le sue tre leggi disciplinatrici. Torin, It.: UTET, 1932.

Bonsignori, Angelo. Il fallimento. Padova, Cedam, 1986.

del Marmol, Charley. La faillite en Droit Anglo-saxon. Etude de législation et de jurisprudence faite dans le cadre de la loi anglaise de 1914. Paris: Librairie Générale de Droit et de Jurisprudence, 1936.

Duffy, Ian. Bankruptcy and Insolvency in London During the Industrial Revolution. London: Garland Publishing, 1985.

Hennebicq, Leon. Principes de droit maritime comparé. Brussels: V.F. Larcier, 19041910.

Hoechster, Ernest. Manuel de droit commercial Francais et étranger, suivant les lois, les coutumes et la jurisprudence. Paris: A. Marescq, 1874.

Lecomte, M. Etude comparée des principales législations européennes en matière de faillite. Paris: Durand et Pedone-Lauriel, 1879.

Lester, V. Markham. Victorian Insolvency: Bankruptcy, Imprisonment for Debt and Company Winding-up in Nineteenth-Century England. Oxford: Oxford University Press, 1994. 
Levy, John. The Law and Practice of Bankruptcy \& Insolvency: Embracing The Irish Bankrupt and Insolvency Act, 1857. Dublin: Hodges, Smith \& Co., 1859.

Lyon-Caen, Charles, and Louis Renault. Traité de droit commercial: Tome 1. Paris: F. Pichon et Durand-Auzias, 1906.

Pajardi, Piero. Il Fallimento nel Mondo: panorama dei sistemi esecutivi concorsuali nelle realta nazionali. Padova: Cedam, 1988.

Rezzara, J. Il concordato nella storia, nella dottrina, nella giurisprudenza: Studio di diritto commerciale. Turin: Roux e Viarengo, 1901.

Robert, Charles. De la liquidation judiciaire des sociétés (Loi du 4 mars 1889). Bordeaux: Imprimerie Y. Cardonet, 1896.

Telfer, Thomas GW. Ruin and Redemption: The Struggle for a Canadian Bankruptcy Law, 1867-1919. Toronto: University of Toronto Press, 2014.

Williamson, Oliver. The Economic Institutions of Capitalism. New York: The Free Press, 1985.

Zavadskij, A. V. “Droit Commercial Russe.” In Les Lois Commerciales de l'Univers, Tome XXXIV, Russie-Pologne. Paris: Librairie générale de droit et de jurisprudence, 1912.

Zweigert, Konrad, and Hein Kötz. An Introduction to Comparative Law. Vol. 1. 2nd ed. Oxford: Clarendon Press, 1987.

Articles and Chapters in Books 
Armour, John. "The Chequered History of the Floating Charge." Griffith Law Review 13, no. 1 (2004): 25-56.

Aston, Jennifer, and Paolo Di Martino. "Risk and Success: Re-assessing Female Entrepreneurship in Late-Victorian and Edwardian England." Economic History Review 70, no. 3 (2017): 837-58.

Astrom, Adolf. "The Commercial and Bankruptcy Law of Sweden.” In The Commercial Laws of the World, Vol. XIX, Sweden and Norway. Edited by William Bowstead London: Sweet \& Maxwell, 1914: 125-157.

Beissel, Pierre, and Sébastien Binard. "Luxembourg." In The International Insolvency Review, edited by Donald Bernstein. London: Law Business Research Ltd, 2015: 200-215.

Benito, Lorenzo. "The Commercial Bills of Exchange, Bankruptcy and Maritime Law of Spain.” In The Commercial Laws of the World, Vol. XXXII, Spain. Edited by William Bowstead, London: Sweet \& Maxwell, 1914: 212-224.

Biryukov, Alexander. "Ukrainian Bankruptcy Law in the Context of Regional and International Developments.” Annual Survey of International \& Comparative Law 13, no. 13 (2007): 13-33.

Block, Kevin. "Ukrainian Bankruptcy Law.” Loyola of Los Angeles International and Comparative Law Review 20, no. 1 (1997): 97-121.

Bolt, Jutta, Robert Inklaar, Herman de Jong, and Jan Luiten van Zanden. "Rebasing 'Maddison': New Income Comparisons and the Shape of Long-Run Economic Development.” Maddison Project Working Paper no. 10. Groningen, 2018. 
Bourbouloux, Hélène, Arnaud Pérès, Juliette Loget, and Pierre Chatelain. "France.” In The International Insolvency Review, edited by Donald Bernstein. London: Law Business Research Ltd, 2015: 166-180.

Brooks, Sid. "Three's a Charm? Russia's Third Bankruptcy Law in Ten Years." International Business Lawyer 30 (2002): 225-26.

Brown, Richard. "Comparative Legislation in Bankruptcy." Journal of the Society of Comparative Legislation 2, no. 3 (1900): 251-70.

Bufford, Samuel. "Romanian Bankruptcy Law: A Central European Example.” New York Law School Journal of International and Comparative Law, 17 (1997): 251-65.

Cepec, Jaka. "Corporate Insolvency Law-A Necessity of Market Economy, Lessons from History and Slovenia.” Acta Histriae 22, no. 3 (2014): 765-90.

Coyle, Christopher, and John Turner. "Law, Politics and Financial Development: The Great Reversal of the U.K. Corporate Debt Market." The Journal of Economic History 73, no. 3 (2013): 810-46.

Cupovic, Carl. "The Laws Relating to Bankruptcy and the Impeachment of Transactions of an Insolvent Debtor for Croatia and Slavonia." In The Commercial Laws of the World, Vol. XXVIII, Hungary and Croatia-Slavonia. Edited by William Bowstead, London: Sweet \& Maxwell, 1914: 146-180.

De ruysscher, Dave. "At the End, the Creditors Win: Pre-insolvency Proceedings in France, Belgium and the Netherlands (1807-c1910)." Comparative Legal History 6, no. 2 (2018): 1-23. 
Di Martino, Paolo. “Approaching Disaster: Personal Bankruptcy Legislation in Italy and England, c.1880-1939.” Business History 47, no. 1 (2005): 23-43.

Di Martino, Paolo. "Legal Institutions, Social Norms, and Entrepreneurship in Britain (c.1890-c.1939)." Economic History Review 65, no. 1 (2012): 120-43.

Di Martino, Paolo, and Pierre-Cyrille Hautcoeur. "The Functioning of Bankruptcy Law and Practices in European Perspective: c.1880-1913." Enterprise and Society 14, no. 3 (2013): 579-605.

Di Martino, Paolo, and Michelangelo Vasta. “Companies' Insolvency and 'the Nature of the Firm' in Italy, 1920s-1970s." The Economic History Review 63, no. 1 (2010): $137-64$.

Fohlin, Caroline. "Does Civil Law Tradition and Universal Banking Crowd Out Securities Markets? Pre-World War I Germany as Counter-Example.” Enterprise \& Society 8 , no. 3 (2007): 602-41.

Freeman, Mark, Robin Pearson, and James Taylor. "Different and Better? Scottish JointStock Companies and the Law, c.1720-1845." English Historical Review 122:495 (2007): 61-81.

Garasic, Jasnica. "New Bankruptcy Law in Croatia." Eurofenix (Autumn 2016): 36-38. https://www.insol-europe.org/download/documents/941.

Gerlach, Helmut. "Bankruptcy in the Czech Republic, Hungary, and Poland and Section 304 of the United States Bankruptcy Code, Proceedings Ancillary to Foreign Bankruptcy Proceedings." Maryland Journal of International Law 22, no. 1 (1998): 81-115. 
Gutiérrez, Carlos López, Myriam García Olalla, Bego na Torre Olmo. “The Influence of Bankruptcy Law on Equity Value of Financially Distressed Firms: A European Comparative Analysis." International Review of Law and Economics 29, no. 3 (2009): 229-43.

Hambro, E. “The Commercial and Bankruptcy Law of Norway.” In The Commercial Laws of the World, Vol. XIX, Sweden and Norway. Edited by William Bowstead, London: Sweet \& Maxwell, 1914: 125-157

Hansen, Bradley. "Commercial Associations and the Creation of a National Economy: The Demand for Federal Bankruptcy Law.” Business History Review 72, no. 1 (1998): 86-113.

Jaatinen, Pekka, and Anna-Kaisa Remes. “Finland.” In The International Insolvency Review, edited by Donald Bernstein. London: Law Business Research Ltd, 2015: $156-165$.

Jaeger, Ernst. "The Imperial Law of Bankruptcy." In The Commercial Laws of the World, Vol. XXIV, German Empire. Edited by William Bowstead, London: Sweet \& Maxwell, 1914: 266-395.

Janda, Karel, and Anna Rakicova. "Corporate Bankruptcies in Czech Republic, Slovakia, Croatia and Serbia.” The Munich Personal RePEc Archive, Paper No. 54109. Munich, 2014.

Kiralfy, Albert. “Insolvency.” In Encyclopaedia of Soviet Law. Edited by Ferdinand Feldbrugge, Gerard Berg, William Simons. Dordrecht: Martinus Nijhoff, 1985. 
Lamoreaux, Naomi, and Jean-Laurent Rosenthal. "Legal Regime and Contractual Flexibility: A Comparison of Business's Organizational Choices in France and in the United States During the Era of Industrialization.” American Law and Economic Review 7, no. 1 (2005): 28-61.

La Porta, Rafael, Florencio Lopez-de-Silanes, and Andrei Shleifer. “The Economic Consequences of Legal Origins." Journal of Economic Literature 46, no. 2 (2008): 285-332.

Levi, Edward H., and James W. Moore. "Bankruptcy and Reorganization: A Survey of Changes." The University of Chicago Law Review 5 no. 1 (1937): 1-40.

Levy, Bela, "The Commercial, Bills of Exchange and Bankruptcy Law of Hungary. "In The Commercial Laws of the World, Vol. XXVIII, Hungary and CroatiaSlavonia. Edited by William Bowstead, London: Sweet \& Maxwell, 1914: 155179.

McDonnell, Robin, Saranna Enraght-Moony, and Karole Cuddihy. "Ireland.” In The International Insolvency Review, edited by Donald Bernstein. London: Law Business Research Ltd, 2015: 219-234.

Musacchio, Aldo. "Can Civil Law Countries Get Good Institutions? Lessons from the History of Creditor Rights and Bond Markets in Brazil." The Journal of Economic History 68, no. 1 (2008): 80-108.

Musacchio, Aldo, and John Turner. "Does the Law and Finance Hypothesis Pass the Test of History?" Business History 55, no. 4 (2013): 521-39. 
Paulus, Christoph, Stathis Potamitis, Alexandros Rokas, Ignacio Tirado. "Insolvency Law as a Main Pillar of Market Economy_A Critical Assessment of the Greek Insolvency Law.” International Insolvency Review 24:1 (2015): 1-27.

Radin, Max. "Discharge in Bankruptcy." New York University Law Quarterly Review IX no.1 (1931): 39-48.

Rohde, Thomas. “Switzerland.” In The International Insolvency Review, edited by Donald Bernstein. London: Law Business Research Ltd., 2015: 410-427

Serra, Catarina. "Amendments to the Portuguese Insolvency Act." Eurofenix, Autumn, 2012: 14-17.

Sgard, Jérôme. "Do Legal Origins Matter? The Case of Bankruptcy Laws in Europe 1808-1914." European Review of Economic History 10, no. 3 (2006): 389-419.

Sjørslev, Henrik, and Dennis Højslet. "Denmark." In The International Insolvency Review, edited by Donald Bernstein. London: Law Business Research Ltd, 2015: $110-121$.

Snertingdalen, Stine D., and Ingrid Tronshaug. "Norway.” In The International Insolvency Review, edited by Donald Bernstein. London: Law Business Research Ltd, 2017: 337-351.

Tambacopoulos, A. "The Bankruptcy Laws of Greece." National Association of Referees in Bankruptcy 8, (1934): 155.

Tufano, Peter. "Business Failure, Judicial Intervention, and Financial Innovation: Restructuring U.S. Railroads in the Nineteenth Century." Business History Review 71, no. 1 (1997): 1-40. 
Walters, Adrian. "Personal Insolvency Law After the Enterprise Act: An Appraisal." Journal of Corporate Law Studies 5, no. 1 (2005): 65-104.

Williams, Paul, and Paul Wade. "Bankruptcy in Russia: The Evolution of a Comprehensive Russian Bankruptcy Code." Review of Central and East European Law 21, no. 5 (1995) 511-32.

\section{Unpublished Materials}

Baranauskaite, Ieva. "Key Insolvency Laws in Lithuania—An Overview.” 2013. http://www.insol.org/emailer/Oct_2013_downloads/Key\%20insolvency\%20Laws _Lithuania.pdf.

Franks, Julian, and Oren Sussman. "Financial Innovation and Corporate Insolvency." Unpublished manuscript, London Business School, 1999.

Hammond-Partnership. "The New Law Regarding Bankruptcy in Romania," by Nicholas Hammond, July 7, 2014. https://hammond-partnership.com/the-new-lawregarding-bankruptcy-in-romania/

Kireeva, Olga. "Belorussian Bankruptcy Law: A Comparative Aanalysis with the American Bankruptcy System.” n.d. http://www.legalhoudini.nl/images/upload/Olga\%20Kireeva.pdf.

Perakis, Evanghelos. “The New Greek Bankruptcy Code: How Close to the InsO?” 2010. http://www.academia.edu/1455030/The_new_Greek_Bankruptcy_Code_How_clo se to the InsO. 
Sallila, Jussi. "Insolvency, Commercial Utility and Principles of Justice: The Making of Bankruptcy Law in Sweden and Finland, ca. 1680-1868.” PhD diss., University of Helsinki, 2016.

Published Reports

Aleth, Franz, and Nils Derksen. Restructuring and Insolvency in 45 Jurisdictions Worldwide: Germany. London: Law Business Research Ltd., 2017.

Andersen, Hendrik, and Lars Skanvig. Bankruptcy and a Fresh Start: Stigma on Failure and Legal Consequences of Bankruptcy. Country report: Denmark. Brussels: EU Enterprise and Industry, Support for Policy Development, 2002.

Broeders, Michael. "Netherlands." In Restructuring and Insolvency in 45 Jurisdictions Worldwide, 295-305. London: Law Business Research Ltd, 2015.

Burniaux, Jean-Marc. "Establishing Financial Discipline: Experience with Bankruptcy Legislation in Central and Eastern European Countries." OECD Economic Studies 25 (1995): $110-51$.

Busi, Claudio. Bankruptcy and a Fresh Start: Stigma on Failure and Legal Consequences of Bankruptcy. Country Report: Finland. Brussels: EU Enterprise and Industry, Support for Policy Development, 2002.

Chatelon, Stephanie, and Guillaume Cornu. Bankruptcy and a Fresh Start: Stigma on Failure and Legal Consequences of Bankruptcy. Country Report: France. Brussels: EU Enterprise and Industry, Support for Policy Development, 2002. 
De Moor, Bart, and Matthew Gibson. Bankruptcy and a Fresh Start: Stigma on Failure and Legal Consequences of Bankruptcy. Country Report: Belgium. Brussels: EU Enterprise and Industry, Support for Policy Development, 2002.

European Commission. Bankruptcy and a Fresh Start: Stigma on Failure and Legal Consequences of Bankruptcy. Brussels: EU Enterprise and Industry, Support for Policy Development, 2002.

European Commission. A Second Chance for Entrepreneurs: Prevention of Bankruptcy, Simplification of Bankruptcy Procedures and Support for a Fresh Start. Brussels: European Commission, 2016.

Felios, Sotiris, and Evangelia Vouza. Bankruptcy and a Fresh Start: Stigma on Failure and Legal Consequences of Bankruptcy. Country Report: Greece. Brussels: EU Enterprise and Industry, Support for Policy Development, 2002.

Fura-Sandström, Elisabet, and Thomas Ehrner. Bankruptcy and a Fresh Start: Stigma on Failure and Legal Consequences of Bankruptcy. Country Report: Sweden. Brussels: EU Enterprise and Industry, Support for Policy Development, 2002.

Gerber, Martine, and Denis Philippe. Bankruptcy and a Fresh Start: Stigma on Failure and Legal Consequences of Bankruptcy. Country Report: Luxembourg. Brussels: EU Enterprise and Industry, Support for Policy Development, 2002.

González de Zulueta, Fernando, Fernando Carvajal, Beatrice Vanden Abeele. Bankruptcy and a Fresh Start: Stigma on Failure and Legal Consequences of Bankruptcy. Country Report: Spain. Brussels: EU Enterprise and Industry, Support for Policy Development, 2002. 
Göttgens, Michael. Bankruptcy and a Fresh Start: Stigma on Failure and Legal Consequences of Bankruptcy. Country Report: Germany. Brussels: EU Enterprise and Industry, Support for Policy Development, 2002.

IMF. World Economic Outlook. Too Slow for Too Long. Washington: IMF, 2016.

Janssen, Marc, Anthony Terng, Jurriaan van der Wulp. Bankruptcy and a Fresh Start: Stigma on Failure and Legal Consequences of Bankruptcy. Country Report: Netherlands. Brussels: EU Enterprise and Industry, Support for Policy Development, 2002.

Kennedy, Brian. Bankruptcy and a Fresh Start: Stigma on Failure and Legal Consequences of Bankruptcy. Country Report: Ireland. Brussels: EU Enterprise and Industry, Support for Policy Development, 2002.

Klauser, Alexander. Bankruptcy and a Fresh Start: Stigma on Failure and Legal Consequences of Bankruptcy. Country Report: Austria. Brussels: EU Enterprise and Industry, Support for Policy Development, 2002.

Maria Pereira, Antonio. Bankruptcy and a Fresh Start: Stigma on Failure and Legal Consequences of Bankruptcy. Country Report: Portugal. Brussels: EU Enterprise and Industry, Support for Policy Development, 2002.

Nagy-Koppány, Kornelia, Abigel Csurdi, and Eva Németh. Restructuring and Insolvency in 45 Jurisdictions Worldwide: Hungary. London: Law Business Research Ltd, 2017. 
O’Brien, Thomas, and Christian Filipov. "The Current Regulatory Framework Governing Business in Bulgaria." World Bank Technical Paper no. 513, The World Bank, Washington, DC, 2001.

Société de Législation Comparé. Annuaire de législation étrangère. Paris: various years. Snertingdalen, Stine D., and Ingrid Tronshaug. Restructuring and Insolvency in 45 Jurisdictions Worldwide: Norway. London: Law Business Research Ltd, 2017. Teklyuk, Yaroslav, and Valeriia Tryfonova. Restructuring and Insolvency in 45 Jurisdictions Worldwide: Ukraine. London: Law Business Research Ltd, 2015.

\section{$\underline{\text { Appendix }}$}

\section{Sources}

Whenever possible, we directly consulted the actual law, either in the original language or translated. This was possible in the following cases: Holland, 1896; Finland, 2004; Ireland, 1872, 1988; Italy, 1842, 1938, 1942, 2006: Serbia, 2004, 2010; Spain, 1885, 1922; UK, 1914, 1986, 2002; Ukraine, 1992.

For the nineteenth century, commercial laws of some countries were published with a comment in their original language alongside a translation in either French or English, in collections of volumes titled The commercial laws of the world (in English) or Les lois commerciales de l'univers (in French). These volumes, published between 1911 and 1914, represented an important source for the reconstruction of the features of laws for countries such as Belgium, Croatia, Denmark, Germany, Hungary, Luxembourg, Norway, Russia, Serbia, Slovenia, Spain, Sweden, and Poland. For the same period, vital information could also be extracted from summaries of legislations published annually 
(in French) in a bulletin edited by the Société de Législation Comparé titled Annuaire de législation étrangère.

For the period after World War II, European Commission documentation has been a key source in the form of sponsored country reports collectively entitled Bankruptcy and a fresh start: stigma on failure and legal consequences of bankruptcy. Although geared toward contemporary issues and policy implications, these reports also provided, often in a very sketchy way, a summary of the historical evolution of bankruptcy and insolvency law.

For both periods, information derived from these sources has been cross-checked and integrated with that available from contemporary or modern comparative analyses, national reports, and various academic studies. Overall, more than one hundred different sources have been consulted. The full list of sources (beyond the ones included in the references) used to generate the database is available from the authors upon request.

\section{$<$ Table A here >}

\footnotetext{
${ }^{1}$ Williamson, The Economic Institutions, 87.

${ }^{2}$ In the nontechnical language, and sometimes in the academic literature, bankruptcy and insolvency tend to be used as synonyms. In fact, the two terms can have different meanings. First, whereas the former indicates a legal status, the latter refers more to an economic condition (the inability to face debt), which might not necessarily lead to formal bankruptcy (see Telfer, Ruin and Redemption, 5). Second, as discussed in the paper, in countries where traders are separated from nontraders, the former are subject to
} 
bankruptcy law, and the latter to insolvency (Brown, "Comparative legislation,” 251).

Finally, in Anglo-Saxon legal regimes, a technical distinction is made between incorporated businesses (subject to insolvency) and individuals, sole ownerships and partnerships, which are dealt with via bankruptcy law. In this paper, we use the term "bankruptcy," although in the case of England and Ireland, however, we also analyze insolvency legislation applying to incorporated business. We do not analyze insolvency as the set of legal devices dealing with nontraders or other legal entities not subject to bankruptcy law.

${ }^{3}$ Lamoreaux and Rosenthal, "Legal Regime and Contractual Flexibility."

${ }^{4}$ Aston and Di Martino, "Risk and success"; Di Martino, "Legal Institutions."

${ }^{5}$ Musacchio, “Can Civil Law Countries Get Good Institutions?”; Freeman, Pearson, and Taylor, "Different and Better?"; Fohlin, "Does Civil Law Tradition."

${ }^{6}$ Di Martino and Vasta, “Companies’ Insolvency.”

${ }^{7}$ Di Martino and Hautcoeur, "The Functioning of Bankruptcy Law."

${ }^{8}$ European Commission, A Second Chance for Entrepreneurs.

${ }^{9}$ Sgard, "Do Legal Origins Matter?"

${ }^{10}$ For the current UK we use just England and Wales. Both Scotland and Northern Ireland (NI) have their own legal systems, which, although similar to English law, do exhibit differences in terms of bankruptcy procedures. However, neither Scotland nor NI are currently independent nations, therefore they have not been included in the sample. 
The Republic of Ireland was part of the UK until 1922, but since 1870 it was covered by separate legislation. Hungary benefited from autonomy since the beginning of the period.

${ }^{11}$ In this regard, the benchmark 1850 was challenging. As Germany did not exist as a nation state prior to 1871 , Prussia has been used as a proxy for the benchmark years 1850 and 1870. Similarly, the Kingdom of Sardinia has been used as a proxy for Italy for the year 1850 as the modern Italian State was created in 1861. Also, we have been unable to find precise information on the Austrian 1781 law (which also applied to Serbia, Czech Republic, Slovenia, Slovakia, and Croatia), whereas in Norway customary nonrecorded norms applied. To solve these problems, for Austria we considered, instead, the 1853 law, passed only three years after the benchmark. For Norway, we used instead Sweden as a proxy, given the strong influence this country had on the development of Norwegian legislation. For instance, the 1863 Norwegian bankruptcy law was considered at the time as widely influenced by the Swedish act passed just one year earlier (see Hoechster, Manuel de droit commercial Francais et étranger). In Romania and Bulgaria, the Turkish 1850 commercial code applied until these countries passed their own commercial codes (Lyon-Caen and Renault, Traité de droit commercial).

${ }^{12}$ It is interesting to note that, although bankruptcy was conceptually impossible during communism, some countries had laws to deal with the phenomenon. Precommunist law in Poland and Romania was not abolished under communism, while a new legislation was passed in 1970s Yugoslavia. In these cases, although these institutions rarely were used, we collected information and included then in the database. Also, we note that no 
information was available for independent Lithuania between World War I and World War II.

${ }^{13}$ Sgard, "Do Legal Origins Matter?"

${ }^{14}$ Di Martino and Hautcoeur, “The Functioning of Bankruptcy Law”; Sgard, "Do Legal Origins Matter?"

${ }^{15}$ Rezzara, Il concordato nella storia, nella dottrina, nella giurisprudenza; Bolaffio, Il concordato preventivo.

${ }^{16}$ Brown, "Comparative legislation in Bankruptcy"; del Marmol, La faillite en Droit Anglo-saxon; Bolaffio, A proposito della riforma del fallimento.

${ }^{17}$ For similar opinions, see Robert De la liquidation judiciaire des sociétés, 1-2;

Bolaffio, Il concordato preventivo, quoted by Di Martino and Hautcouer, "The Functioning of Bankruptcy Law," 583. For analysis of the impact of cultural change on the severity of bankruptcy, see, among many others, Duffy, Bankruptcy and Insolvency in London, and Lester, Victorian Insolvency.

${ }^{18}$ Although similar in meaning, these solutions have been called different names, such as nonbankruptcy arrangements or compositions, or pre-insolvency proceedings or arrangements.

${ }^{19}$ Sgard, "Do Legal Origins Matter?"; De ruysscher, "At the End, the Creditors Win.”

${ }^{20}$ See Brown, "Comparative Legislation in Bankruptcy” for France, and Radin, "Discharge in Bankruptcy," for England. 
${ }^{21}$ Di Martino, “Approaching Disaster”; Di Martino and Hautcoeur, "The Functioning of Bankruptcy Law.”

${ }^{22}$ Bonsignori, Il fallimento.

${ }^{23}$ As argued by Robert, toward the end of the nineteenth century, "La liquidation judiciaire et la faillite sont deux procédures qui ... tendent au même but, la sauvegarde des intérêts des créanciers" ("liquidation judiciaire and faillite are two procedures ... aiming at the same goal, the safeguard of creditors interests"), from Robert, De la liquidation judiciaire des sociétés, 11 . This view has been recently reinforced by De ruysscher. Describing the aim of prebankruptcy proceedings, he argues: "Legislators could secure the cooperation of insolvents, but this was not per se combined with efforts of continuity of business or corporate rescue," from De ruysscher, "At the End, the Creditors Win," 3.

${ }^{24}$ We do not include special procedures only open to specific debtors, such as cooperative firms, insurance companies, banks, etc.

${ }^{25}$ For instance, we did not include the reforms passed in France (1905), Austria (Law 16 March 1884, G.U. n.35 and n. 36), and Greece (Law of 22 February 1910). Conversely, we included as "change" the laws passed in Germany (1898), Italy (1865), and Ireland (1872), given that formally they fully replaced the preceding law.

${ }^{26}$ For instance, English judges' acceptance of the so-called floating charge is considered to have profoundly changed the functioning of corporate insolvency law, see Franks and Sussman "Financial Innovation." However, the extent to which such developments in 
judicially sanctioned law continued into the twentieth century has been open to debate, see Armour "Floating Charge" and Coyle and Turner "Law, Politics, and Financial Development."

${ }^{27}$ Both the database and the list of sources by country are available on request. ${ }^{28}$ The legal origins concept — the idea that nations belong to specific legal families—was originally developed by legal scholars such as Zweigert and Kötz (An Introduction to Comparative Law). It has subsequently been used by economists to analyze the pattern of development of national legislation over time. This approach tries to explain why some countries (the ones belonging to the Anglo-Saxon group) tend to have legal institutions more suitable to promote long-term growth (for an overview of this literature, see La Porta, Lopez-de-Silanes, and Shleifer, “The Economic Consequences”). This approach has been challenged by business historians—-for a recent survey, see Musacchio and Turner, "Does the law and finance hypothesis".

${ }^{29}$ In constructing this variable we include countries that later became independent but were, at the time, part of bigger political entities that possessed bankruptcy institutions. For example, countries such as Belarus, Lithuania, and Poland, which were part of the Russian empire, or areas under the Austrian rule. Conversely, we do not include independent countries (such as Belgium or Norway), which used customary solutions or legislation/commercial codes developed by other independent countries.

${ }^{30}$ Countries have been classified according to La Porta, Lopez-de-Silanes, and Shleifer in "The Economic Consequences." Communist countries, not analyzed by La Porta et al., 
have been classified in the German family if previously part of the Austro-Hungary empire, or in the French family if originally part of the Russian Empire. Rumania is classified as belonging to the French family. Bulgaria adopted German law in all areas but in bankruptcy, for which it used the French model (Société de Législation Comparé, Annuaire de législation étrangère 1898), hence it is considered as part of the French family.

${ }^{31}$ See Bonsignori, Il fallimento, for Italy, Tambacopoulos, "The Bankruptcy Laws of Greece" for Greece, and De ruysscher, "At the End, the Creditors Win" for Belgium and Holland.

${ }^{32}$ This was certainly the case in 1930s Greece, when scholars argued that "provisions on Bankruptcy of the Greek Commercial Law are now considered as antiquated ones, the modern Law on bankruptcy not having been taken into view, as for instance the German one.” Tambacopoulos, “The Bankruptcy Laws of Greece," 155.<AQ>Okay to close quotation marks after "one"? $</ \mathrm{AQ}>$

${ }^{33}$ Sgard, "Do Legal Origins Matter?"

${ }^{34}$ See, Levi and Moore, "Bankruptcy and Reorganization," for the United States, and del Marmol, La faillite en Droit Anglo-Saxon, for continental Europe.

${ }^{35}$ See, De ruysscher, "At the End, the Creditors Win," for Holland, and Bonsignori, Il fallimento, for Italy. 
${ }^{36}$ Several changes occurred relatively early in the crisis: Yugoslav law changed in 1930 (accounting for three instances of change, as it covered modern-day Croatia, Serbia, and Slovenia), whereas Slovak and Czech laws changed in 1931.

${ }^{37}$ Levi and Moore, "Bankruptcy and Reorganization," 9.

${ }^{38}$ Burniaux, "Establishing Financial Discipline"; Janda and Rakicova, "Corporate Bankruptcies in Czech Republic"; Cepec, "Corporate Insolvency Law."

${ }^{39}$ Given the relative low number of countries with such procedures, in figure 8 we do not distinguish between the total sample and countries always included in it.

${ }^{40}$ Robert, De la liquidation judiciaire.

${ }^{41}$ Di Martino and Vasta, “Companies’ Insolvency”; Di Martino and Hautcoeur, "The Functioning of Bankruptcy Law.”

${ }^{42}$ For the sake of consistency with table 2, we only include independent countries. 